\title{
BIOLOGICAL EFFECTS OF AIRBORNE POLLUTANTS RELEASED DURING CEMENT PRODUCTION ASSESSED WITH LICHENS (SW SLOVAKIA)
}

3

\author{
Luca Paoli ${ }^{1}$, Anna Guttová ${ }^{2}$, Alice Grassi ${ }^{1}$, Anna Lackovičová2 ${ }^{2}$ Dušan Senko ${ }^{2}$, Stefano Loppi ${ }^{1, *}$ \\ ${ }^{1}$ Department of Life Science, University of Siena, via Mattioli 4, 53100 Siena, Italy; \\ ${ }^{2}$ Institute of Botany, Slovak Academy of Sciences, Dúbravská cesta 9, 84523 Bratislava, Slovakia
}

\begin{abstract}
In this paper we investigated the biological effects of airborne pollutants released during cement production by means of epiphytic lichens (SW Slovakia). We assessed the effects of dust pollution on lichen diversity around a limestone quarry (on the quarry-facing and the opposite side of Fagus sylvatica boles) and the content of selected elements in samples of the lichen Xanthoria parietina collected around a cement mill, two quarries and urban and rural sites at increasing distance from the sources of pollution. Dust contamination from limestone quarrying affected lichen diversity within a distance of $350 \mathrm{~m}$ from the source. The analysis of the functional traits of the lichen diversity was particularly helpful as indieator of dust pollution. Approaching the quarry, the diffusion of basi-nitrophilous species, the decrease of acidophilous species and the asymmetrical distribution of lichens on the tree boles, with a higher coverage of basiphilous species in the side facing the source of dust were observed. These responses, based on the functional traits of the lichen diversity, are helpful in monitoring studies around similar sources of pollution. In samples of $X$. parietina collected around the quarries and the cement mill, $\mathrm{Ca}, \mathrm{Ti}, \mathrm{Fe}, \mathrm{V}, \mathrm{Al}$ and $\mathrm{Ni}$ were significantly higher than in the surrounding environment. Calcium was a good tracer for dust contamination around the quarries and the cement plant and a clear decrease in its content with increasing distance from the source was found, with normal values reached within $1,700 \mathrm{~m}$ from the cement mill. Lichens can be successfully used as indicators to integrate instrumental monitoring networks, when air pollution from cement factories is concerned.
\end{abstract}

Keywords: Air pellution, Bioindicators, Bioaccumulation, Cement, Dust, Lichens, Xanthoria parietina

* Corresponding author. E-mail address: stefano.loppi@unisi.it (S. Loppi)

\section{Introduction}

Global cement production in 2012 has been estimated at 3.6 billion tonnes, translating into a $+3 \%$ increase compared to 2011, with China representing 59.3\% of the world's total cement production (Cembureau, 2012). During cement production, pollutants may be released to the environment from quarrying and grinding of the raw material, kiln operations, transportation, power generation and packing and dispatch of the cement from the industry. Rock quarrying, grinding and kiln operations are source of coarse and fine particulate matter, which, transported by the wind, may deposit in the surroundings (Bluvshtein et al., 2011) and may have an environmental impact on local vegetation and productivity, affecting crops, grasslands, trees, bryophytes and lichens, via physical or chemical effects (Farmer, 1993; Loppi and Pirintsos, 2000). Power generation from combustion processes can be a source of airborne pollutants from the cement mill that affects the surrounding environment. Such pollutants include $\mathrm{SO}_{2}, \mathrm{NO}_{x}, \mathrm{CO}_{2}$, particulate matter and heavy metals and potentially, dioxins and furans in case of waste burning (Ali et al., 2011; Schuhmacher et al., 2004). Lichens are suitable bioindicators of the effects of air pollution, providing reliable information on the quality and characteristics of the environment (Nimis et al., 2002). Lichens are perennial, slowgrowing organisms that maintain a fairly uniform morphology in time, are highly dependent on the atmosphere for nutrients, and do not shed parts as readily as vascular plants. The lack of a waxy cuticle and stomata allows many contaminants to be absorbed over the whole lichen surface (Ferry et al., 1973). Bioaccumulation involves the absorption and release of molecules with the 
surrounding environment, as a result of the balance between biotic and abiotic components of ecosystems and biogeochemical cycles (Bačkor and Loppi, 2009; Garty, 2001). Lichen monitoring can be used as a complementary system that integrates instrumental monitoring around point sources of atmospheric pollution. Consequently, epiphytic lichens can be profitably used for monitoring dust fallout and the effects of dust contamination (Loppi and Pirintsos, 2000). Dust pollution was shown to influence lichen diversity (Loppi and Pirintsos, 2000; Marmor et al., 2010), element accumulation (Branquinho et al., 2008) and physiological processes of lichen thalli (Zaharopoulou et al., 1993). In general, alkaline dust pollution increases bark $\mathrm{pH}$ and consequently enhances the diffusion of basiphilous species (Marmor et al., 2010) at the expense of acidophilous ones (Loppi and Pirintsos, 2000). Calcium content of lichens exposed to dust pollution near a cement industry is considered the foremost cement-dust indicator (Branquinho et al., 2008). Several studies associated cement production to the release of high loads of $\mathrm{Ca}$ into the atmosphere (see e.g. the review of Garty and Garty-Spitz, 2011). Furthermore, heavy metals released from cement industries powered by means of fossil fuels and/or waste burning (Schuhmacher et al., 2004) can be detected in topsoils (Bermudez et al., 2010) and in native and transplanted lichens (Demiray et al., 2012; Ljubič Mlakar et al., 2011).

The presence of a cement mill near Bratislava (SW Slovakia), offered the opportunity to investigate in the field the biological and chemical effects of airborne pollutants released during cement production, with an emphasis on dust pollution.

This work was carried out to investigate: i) the impact of dust pollution from limestone rock quarrying on epiphytic lichen diversity in relation to angular exposure and distance from the source; and ii) the impact of airborne pollutants from the cement production in the surrounding environment, analysing the accumulation of selected elements in native lichens.

\section{Material and Methods}

\subsection{Study area}

The study area extends over ca. $32 \mathrm{~km}^{2}$ (Fig. 1). The cement plant, operating since the 1970s, is located ca. $40 \mathrm{~km}$ NE of Bratislava (SW Slovakia), on the foot of the Malé Karpaty Mts, surrounding it to the $\mathrm{S}$ and $\mathrm{E}$. The landscape is rural, characterized by arable land, pastures and forests (beech and mixed oak, hornbeam, linden and maple). Elevation ranges between 200 and 450 $\mathrm{m}$ asl. The climate is continental, with an average annual rainfall of ca. $700 \mathrm{~mm}$. Prevailing winds flowards SE (ea. $40 \%$ ) or NW (ea. 20\%) with an a speed intensity of $3.7 \mathrm{~m} / \mathrm{s}$ in both direens (Lapin el., 2002). The closest town (3,500 inhabitants) is located $1.5 \mathrm{~km} \mathrm{~W}$ of the cement mill.

Currently, the average capacity of the cement mill is $150,000 \mathrm{t} / \mathrm{y}$ of clinker and $160,000 \mathrm{t} / \mathrm{y}$ of cement The raw material is extracted in a limestone $\left(\mathrm{CaCO}_{3}\right)$ quarry with an operating capacity of 1 $750000 \mathrm{t} / \mathrm{y}$. The material has a fraction of $\mathrm{MgO}$ ranging from $2.2 \%$ to $10.9 \%$ (dolomitic limestone) (www.enviroportal.sk). Nearby, a paleobasalt quarry is situated, with an operating capacity of $600,000 \mathrm{t} / \mathrm{y}$; the material extracted here is chiefly addressed to the market and is characterized by a share of $\mathrm{SiO}_{2}(52-57 \%), \mathrm{MgO}(5-12 \%), \mathrm{CaO}$ (ca. 10\%), $\mathrm{FeO}$ and $\mathrm{Fe}_{2} \mathrm{O}_{3}(5-14 \%), \mathrm{Al}_{2} \mathrm{O}_{3}(<14 \%)$, $\mathrm{TiO}_{2}(0.5-2 \%)$ and traces of $\mathrm{Na}_{2} \mathrm{O}$ and $\mathrm{K}_{2} \mathrm{O}$. The production of grey cement is powered by waste $(68 \%)$, coal $(21 \%)$, petroleum coke and gas burning (11\%), while the production of white cement by petroleum coke $(51 \%)$, waste $(28 \%)$ and gas burning $(21 \%)$; with increasing trend regarding the share of waste (Anonymous, 2011). Airborne emissions from the cement mill are available through continuous instrumental monitoring (yearly average [legal limit]) (www.holcim.sk):

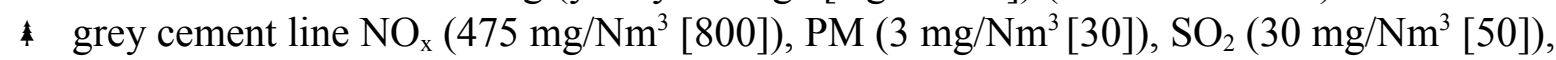
TOC (31 mg/ $\left.\mathrm{Nm}^{3}[60]\right), \mathrm{HCl}\left(4 \mathrm{mg} / \mathrm{Nm}^{3}[10]\right)$;

4 white cement line $\mathrm{NO}_{\mathrm{x}}\left(732 \mathrm{mg} / \mathrm{Nm}^{3}\right.$ [800]), PM (3 mg/ $\left.\mathrm{Nm}^{3}[30]\right), \mathrm{SO}_{2}\left(188 \mathrm{mg} / \mathrm{Nm}^{3}\right.$ [300]), TOC (6 mg/ $\left.\mathrm{Nm}^{3}[10]\right), \mathrm{HCl}\left(7 \mathrm{mg} / \mathrm{Nm}^{3}[10]\right)$.

\subsection{Lichen diversity}


105 To investigate the impact of dust deposition around the limestone quarry, the diversity of epiphytic

106 lichens on Fagus sylvatica trees was measured, being the site surrounded by a mature Fagus forest, 107 where suitable trees are available. Thirty trees, randomly selected along a belt surrounding the 108 border of the quarry (15) and along a belt at a distance of ca. $350 \mathrm{~m}$ from the border of the quarry

109 (15) were sampled (Fig. 1). The latter was selected after a preliminary assessment of lichen 110 distribution, being also the spatial limit of the spontaneous Fagus forest directly surrounding the 111 quarry.

112 The diversity of epiphytic lichens was scored using the index of lichen diversity (ILD) suggested by 113 Pišút and Pišút (2006). The ILD was calculated as the sum of vitality and abundance of epiphytic 114 lichens on the bole (girth $>90 \mathrm{~cm}$ ) at $0-2 \mathrm{~m}$ above ground of isolated trees or on trees distant at least $11510 \mathrm{~m}$ from the closest one. Vitality and abundance of each lichen species were expressed using a 116 specific scale combining both parameters (Lackovičová, 1982; Pišút and Lisická-Jelínková, 1974): $1171=$ one or a few normally developed thalli, or scattered dying out thalli; $3=$ numerous damaged 118 thalli, or scattered healthy thalli; $5=$ frequent healthy thalli. The ILD of each monitoring site was 119 taken as the arithmetic mean of the ILD measured for each sampled tree.

120 The dataset collected for this study was supplemented with relevés collected with the same methodology in 1970s by A. Lackovičová. Eight sampling sites were studied on natural Fagus stands within the same area (Vajarská - Vel'ký Petrklín, Fig. 1) before the opening of the quarry (unpublished data).

To investigate the influence of angular exposure to the quarry, the lichen diversity was sampled separately on the quarry-facing side of the bole and the sheltered side, by dividing the tree circumference into two semi-circumferences and expressing the diversity as the sum of ILD values per each side. To avoid any effect of subjectivity and ensure data quality, each measurement was carried out and double-checked by at least two skilled operators.

Besides total lichen diversity, for data interpretation, ILD values were calculated grouping the species according to their functional value: from previous studies it was reported that dust pollution from limestone quarries and cement works had a neutralizing effect on tree barks, promoting lichen assemblages typical of trees with alkaline barks (Gilbert, 1976; Jürging, 1975; Recchia and Polidoro, 1988). Therefore, we compared ILD values determined by basiphilous species vs ILD values of acidophilous species. Species were assigned to their functional group according to the ecological indicator values reported in the database by Nimis and Martellos (2008); concerning pH of the substratum, species with the score 4-5 were evaluated as basiphilous (slightly basic substrata, i.e. loving dust-covered barks), species with the score 1-2 were evaluated as acidophilous. Species nomenclature follows Guttová et al. (2013). In case of identification problems during field sampling, specimens were collected and identified later in the laboratory. Species belonging to the genus Lepraria and juvenile (undeveloped) thalli of Physcia and Lecanora have been determined up to the genus level.

\subsection{Element accumulation}

To investigate element accumulation in native samples of the lichen Xanthoria parietina, several sites were selected (see Fig. 1), corresponding to potential pollution sources, namely a cement mill (1), a limestone quarry (2) and a paleobasalt quarry (3) and potential target sites, namely inhabited (4) and agricultural areas $(5,6)$. Within each site, lichen thalli were collected (July 19 ${ }^{\text {th }}, 2011$, after 2 weeks of sunny days) at 50-200 cm from the ground, from 3-5 different sampling points, each corresponding to a tree (mainly Acer, Fagus or Prunus). At least 30 different lichen thalli were collected at each site, placed in paper bags, air-dried and stored.

In the laboratory, Xanthoria samples were carefully cleaned under a binocular microscope to remove extraneous material deposited onto the surface, such as remnants of mosses, bark and soil particles. Only the peripheral parts of the lobes (up to $5 \mathrm{~mm}$ from lobe tips) were selected for the analysis; this part roughly corresponds to the biomass produced during the last year. Samples were not washed since there is evidence that washing may unpredictably alter the chemical composition of the thalli (Bettinelli et al., 1996). 
Unwashed samples were pulverized and homogenized with a ceramic mortar and pestle. About 200 $\mathrm{mg}$ of powdered lichen material was mineralized with a mixture of $6 \mathrm{~mL}$ of $70 \% \mathrm{HNO}_{3}, 0.2 \mathrm{~mL}$ of $60 \% \mathrm{HF}$ and $1 \mathrm{~mL}$ of $30 \% \mathrm{H}_{2} \mathrm{O}_{2}$ in a microwave digestion system (Milestone Ethos 900 ) at $280^{\circ} \mathrm{C}$ and 55 bars. The concentrations of selected elements (As, Cd, Cr, Fe, $\mathrm{Hg}, \mathrm{Mn}, \mathrm{Ni}, \mathrm{Pb}, \mathrm{V}$ ) were determined by ICP-MS (Perkin Elmer - Sciex, Elan 6100) or alternatively (Al, Ca, Cu, S, Ti, Zn) by ICP-OES. Results were expressed on a dry weight basis $(\mu \mathrm{g} / \mathrm{g} \mathrm{dw})$. Analytical quality was checked with the Standard Reference Material IAEA-336 'lichen' and GBW-07601 'tobacco'. elements.

\subsection{Bark pH}

The pH of Fagus sylvatica bark was measured following a standard method by Härtel and Grill, as reported in Farmer et al. (1990). Pieces of bark from 10 trees were collected and the upper layer, ca. $3 \mathrm{~mm}$ thick, was cut into pieces and mixed, then $4 \mathrm{~g}$ were put into $30 \mathrm{~mL}$ distilled water. After extraction for $24 \mathrm{~h}(\mathrm{n}=3)$, the $\mathrm{pH}$ of the extract was measured with a $\mathrm{pH}-$ meter (Eutech Instruments $\mathrm{pH}$ 510).

\subsection{Statistics}

The significance of differences between ILD at the limestone quarry and 350 away and between the exposed and sheltered side of the boles were checked using the Kolmogorov-Smirnov test $(p<0.05)$. Differences in species composition of epiphytic lichen communities were analysed by detrended correspondence analysis (DCA), programme package CANOCO 4.5 (ter Braak and Šmilauer, 2002).

The Kolmogorov-Smirnov test $(P<0.05)$ was used to check whether element depositions in Xanthoria parietina at the limestone quarry, the paleobasalt quarry, the cement mill and the closest urban area are significantly higher respect to the agricultural sites of the surrounding environment. After normalization of the data, Pearson correlation coefficient was used to find significant relationships $(p<0.05)$ between pairs of elements.

A GIS model of Ca depositions in X. parietina was created using GRASS GIS v6.4, released under the GNU/GPL license. In the first step, a sum of measured values (concentration in $\mu \mathrm{g} / \mathrm{g} \mathrm{dw}$ ) for each element was calculated. Then these sums were normalized, in such a way that the resulting value for the element with the lowest count of occurrence was equal to one. The coefficient was used to divide each table row for each element. The output were normalized theoretical values for each element and locality that we would have measured in the case that every element was equally present at all localities. A Digital Terrain Model was used to calculate the initial derivations of elevation, slope angle and slope aspect, for the development of a geographically weighted regression, using $\mathrm{Ca}$ as leading factor. The model also accounted for wind direction and intensity, based on data from the national meteorological service (Slovak Hydrometeorological Institute, www.shmu.sk). The model was calculated using Regularized Spline with Tension (RST) (Mitášová and Mitáš, 1993) implemented as a v.surf.rst and v.vol.rst modules. RST allows local spatial prediction to be performed in a flexible and robust way. The v.vol.rst interpolates values to a 3dimensional raster map from 3-dimensional point data given in a 3-D vector point.

\section{Results}

\subsection{Lichen diversity}

Twenty-five lichen species were recorded on F. sylvatica trunks (Tab. 1). Owing to natural bark properties, lichen communities on beech are typically characterized by the dominance of acidophilous species. Within the study area, at a distance of $350 \mathrm{~m}$ from the limestone-quarry, acidophilous species dominated lichen communities (12 out of 15 species) and basi-nitrophilous species contributed only $5 \%$ to the overall ILD value. The proximity to the quarry enhanced the occurrence of basi-nitrophilous lichens (10 out of 18 species). The average ILD value increased 
from $17 \pm 5$ to $30 \pm 10$ and the share of basi-nitrophilous lichens rose from $5 \%$ to $60 \%$. The average $\mathrm{pH}$ of beech bark increased from $5.3 \pm 0.3$ to $5.9 \pm 0.3$ approaching the quarry (Tab. 1).

211 DCA arranged the relevés measured during the present study into two well defined groups, 212 reflecting the share of basi-nitrophilous and acidophilous species in connection with distance from the quarry (Fig. 2). The relevés on the trees surrounding the quarry form a compact cluster characterized by the dominance of basi-nitrophilous species (e.g. X. parietina, Physcia adscendens, Phaeophyscia orbicularis). The relevés on the trees at $350 \mathrm{~m}$ from the limestone-quarry are characterized by the prevalence of acidophilous species, e.g. Pyrenula nitida, Porina aenea, Arthonia radiata. The latter are similar to the relevés carried out in the past in natural beech forests, which form a distinct group with additional dominating acidophilous species e.g. Hypogymnia physodes, Cladonia spp. (only basal squamules), Pertusaria amara. Comparing present and past (1970s) relevés, basiphilous species are clearly spread in the surroundings of the quarry. In addition, an asymmetrical distribution of the lichens around the bole was observed on the border of the quarry, where the side of the trees directly facing the quarry was strongly colonized by basinitrophilous lichens respect to the sheltered side (Fig. 3).

\subsection{Element accumulation}

In samples of $X$. parietina collected around the quarries and the cement mill, $\mathrm{Ca}, \mathrm{Ti}, \mathrm{Fe}, \mathrm{V}, \mathrm{Al}$ and $\mathrm{Ni}$ were significantly higher than in the surrounding environment (Tab. 2). In particular, the highest levels of $\mathrm{Al}, \mathrm{Fe}, \mathrm{Hg}, \mathrm{Mn}, \mathrm{Ti}$ and $\mathrm{V}$ were measured around the paleobasalt quarry. The highest concentration of $\mathrm{Ca}(2460 \mu \mathrm{g} / \mathrm{g})$ was measured at the cement mill and was 2.4 fold higher than the background value of the study area $(1070 \mu \mathrm{g} / \mathrm{g})$. A model of Ca depositions in the area is shown in Figure 4. Lichens from the inhabited area had the lowest content of $\mathrm{Al}, \mathrm{Fe}, \mathrm{Mn}, \mathrm{Ni}$, Ti and $\mathrm{V}$, but were enriched in $\mathrm{Ca}(1450 \mu \mathrm{g} / \mathrm{g})$.

Positive correlations were found between Al-Ti, Al-Fe, Al-Mn, Al-V, Ti-Fe, Ti-Mn, Ti-V, Fe-Mn, $\mathrm{Fe}-\mathrm{V}, \mathrm{Mn}-\mathrm{V}$ and also $\mathrm{Hg}-\mathrm{Ti}, \mathrm{Hg}-\mathrm{Fe}, \mathrm{Hg}-\mathrm{Mn}, \mathrm{Hg}-\mathrm{V}$, suggesting their common terrigenous origin (Tab. 3). The concentrations of the other elements ( $\mathrm{As}, \mathrm{Cd}, \mathrm{Cr}, \mathrm{Cu}, \mathrm{Pb}, \mathrm{Zn}$ ) suggested a low contamination by airborne pollutants from combustion processes (Bargagli and Nimis, 2002), exceptions being $\mathrm{S}$ and Ni. In fact, all sampling sites were affected by a high level of $\mathrm{S}$ in the lichens $(2940-5720 \mu \mathrm{g} / \mathrm{g})$. The content of Ni indicated a condition of moderate pollution $(>3 \mu \mathrm{g} / \mathrm{g})$ around the cement mill and the quarries, and of low pollution $(\leq 3 \mu \mathrm{g} / \mathrm{g})$ at the other sites.

\section{Discussion}

\subsection{Lichen diversity}

The results of the present study indicated a strong influence of dust on epiphytic lichen communities in the surroundings of the limestone quarry and the functional traits of the lichen diversity have been particularly helpful as indicators of dust pollution. Alkaline dust from limestone quarries and cement works has a neutralizing effect on tree barks, promoting lichen assemblages typical of trees with alkaline barks (e.g., Physcia spp. and Xanthoria spp.). Previous studies showed that alkaline dust causes a rise in bark $\mathrm{pH}$, leading to hypertrophication and replacement of acidophilous lichens with xero-nitrophilous ones. This phenomenon is particularly relevant approaching cement mills (Recchia and Polidoro, 1988), quarries (Gilbert, 1976; Loppi and Pirintsos, 2000), dirt roads (Loppi, 1996) and agricultural areas (Loppi and De Dominicis, 1996), especially in arid environments (Paoli et al., 2006). In the proximity of quarries, independently whether alkaline or acid dust is deposited, epiphytic lichens seems to be influenced directly by the physical effect of the deposited dust, and up to $50 \mathrm{~m}$ from the quarries, all species can be regarded as nitrophilous (Loppi and Pirintsos, 2000). Branquinho et al. (2008) estimated that the direct impact of dust around a cement factory (in Portugal) was in the range $250-1000 \mathrm{~m}$ from the source. Cement dust had a hygroscopic effect (Branquinho et al. 2008), which may contribute to the increase of xerophilous lichens approaching the source of dust (Loppi and Pirintsos, 2000; Recchia and Polidoro, 1988). Dust deposition around limestone quarries was found to raise bark $\mathrm{pH}$ of 
Fraxinus excelsior from 3.5 to 6.5 (Gilbert, 1976) and correlations among species diversity, bark pH magnesite works was found to increase bark $\mathrm{pH}$ of Malus domestica and stimulate the diffusion of nitrophilous lichen communities with dominating X. parietina (Pišút and Pišút, 2006). Alkaline dust pollution may increase bark $\mathrm{pH}$ and the proportion of dust indicator species both according to the distance from the source and the vertical gradient in the tree canopy, wherever the highest and exposed part of the canopy correspond to the highest share of basiphilous species (Marmor et al., 2010). Similarly, in our study bark pH of F. sylvatica rose from 4.9 (min) to 6.3 (max) approaching the limestone quarry and the lichen vegetation was clearly enriched in basi-nitrophilous species. According to Loppi and Pirintsos (2000), wind-blown dust can create xeric microclimatic conditions and high deposition of alkaline dust leads to a shift of lichen communities dominated by meso-acidophilous species of weakly eutrophicated environments, such as Flavoparmelia caperata and Parmotrema perlatum, to communities dominated by basi-nitrophilous and xerophilous species, such as Physcia spp. and X. parietina (Loppi, 1996).

Other studies showed that approaching cement factories the lichen vegetation is enriched in basiphilous and xerophilous species, but in the close proximity to the factories an area devoid of any lichen could be found (Recchia and Polidoro, 1988; Recchia et al., 1991). In fact, extreme loads of alkaline dust may heavily affect also basiphilous and nitrophilous lichens, leading to a condition of lichen desert approaching the source of pollution (Loppi and Pirintsos, 2000; Pišút and Pišút, 2006). Gilbert (1976) found a zonation of lichens around a lime dust source in England. Heavily dusted trees had few lichens and this zone was followed by a zone containing lichens that are normally saxicolous together with species typical of highly eutrophicated habitats. Lichen diversity and coverage both increase with the distance from cement mills (Recchia and Polidoro, 1988). Jürging (1975) reported that dust from cement factories has the same effect of ammonia emissions on nearby lichen communities, promoting nitrophilous species. However, at least in the present study, the strongest impact of quarrying operations extends up to a maximum of $350 \mathrm{~m}$ from the source. Likely owing to the buffering capacity of the forest belt surrounding the quarry, at this distance the lichen vegetation is much less influenced by dust and resembles natural assemblages, but is still lacking several species which are typically found on Fagus trunks at remote areas and were present in the study area in the past.

Our data revealed an asymmetrical distribution of lichens on the boles near the quarry, where the diffusion of dust from the quarry clearly promoted the functional group of basiphilous species and reduced acidophilous ones. Studies on the distribution of lichens on road lining trees influenced by car traffic suggested that the more/less turbulent diffusion of pollutants may be the cause for similarities/differences in angular distribution of lichen thalli and their element contents around the bole (Del Guasta, 2000; Paoli et al., 2013). In the case of the quarry, with particles of higher dimensions and a less turbulent dust diffusion, the sampling aspect becomes more critical in the design of a sampling procedure, as suggested by Adams and Gottardo (2012).

The study of the lichen diversity indicated that in the assessment of the biological effects of dust pollution around quarries and cement mills with lichens, functional response groups are particularly helpful. The signals to be searched gradually approaching the source of dust pollution are: increase of basi-nitrophilous and xerophilous species; decrease of acidophilous species; higher share of basiphilous lichens in the side facing the source of dust; and, lastly, the disappearance of lichens at heavily dusted sites.

\subsection{Element accumulation}

All stages of cement production, from extraction of the raw material to the production itself, can be a source of dust pollution (Branquinho et al., 2008; Carreras and Pignata, 2002; Jalkanen et al., 2000; Pignata et al., 2007).

In our study, the high correlations among soil/rock related elements in the lichen X. parietina and the high content of $\mathrm{Ca}$ in native lichens around the cement mill and the quarries suggest a common source, namely dust released during quarrying, grinding of the raw material, transportation, and kiln 
operations for the production of cement. We found out that $\mathrm{Ca}$ in lichens is a good tracer for dust

314 contamination around the quarries and the cement plant, as suggested by Branquinho et al. (2008).

315 In their study, dust pollution around a cement industry was investigated by means of native $(X$.

316 parietina) and transplanted (Ramalina canariensis) lichens. A marked decrease in Ca content in $X$.

317 parietina with increasing distance from the cement mill was found. At approximately $250 \mathrm{~m}$ from

318 the source, Ca reached a background value of $1,377 \mu \mathrm{g} / \mathrm{g}$, whereas at the cement mill, Ca was up to 20 times higher (Branquinho et al., 2008). In our study, according to the model of Ca depositions, the concentrations of this element reach normal values in lichen thalli within $1,700 \mathrm{~m}$ from the cement mill.

In lichens, $\mathrm{Ca}$ is generally present for the vast majority in extracellular form, whereas only a little part occurs intracellularly (Garty and Garty-Spitz, 2011) and SEM observations revealed that cement dust particles can be also included within the thallus (Recchia et al., 1991).

Calcium dust may react differently depending on the wet or dry period (Garty and Garty-Spitz, 2011). In fact, according to Branquinho et al. (2008), two kinds of dust can be observed in relation to cement production. One kind is a cement/clinker dust which produces a thick layer and accumulates in the lichens in wet periods: in this case the increase of $\mathrm{Ca}$ from cement/clinker dust is coincident with an increasing volume of precipitation whereas a decrease may coincide with an increasing number of dry days. On the other hand, Ca-dust derived from small and lose particles of limestone may accumulate in dry periods, being washed off with increasing volumes of rain (Branquinho et al., 2008). It is therefore suggested that lichens are very helpful to detect the spatial impact of Ca-containing dust, whereas when interpreting the temporal impact it is important to account for wet and dry periods differently affecting the accumulation of this element. The decrease of contamination occurring with distance from cement plants can be detected also analysing soil samples: soil contamination drops with distance and with increasing depth from surface (Asubiojo et al., 1991; Bermudez et al., 2010). Soils monitored around a cement factory in Nigeria were enriched in $\mathrm{Ca}, \mathrm{S}, \mathrm{Ni}, \mathrm{Zn}$ and $\mathrm{Cu}$. The enrichment of $\mathrm{S}$ was supposed to originate from $\mathrm{CuSO}_{4}$ component of cement rather than from fuel burning (Asubiojo et al., 1991). We found out a significant correlation between $\mathrm{S}$ and $\mathrm{Cu}$ in our lichens. Carreras and Pignata (2002) reported that $\mathrm{S}$ levels in transplanted lichens were not associated with emissions from a cement industry in Cordoba (Argentina). Also Branquinho and co-workers (2008) did not find relationships between S concentrations in lichens and potential sources of pollution in their study area.

Sulphur is an element typically associated with fossil fuels combustion and epiphytic lichens are extremely effective as biomonitors of S contamination, e.g. around geothermal sources (Loppi, 1996; Loppi et al., 1998). In the study area all sites were concerned by a high level of S in $X$. parietina $(2,940-5,720 \mu \mathrm{g} / \mathrm{g})$. Richardson (1981) reported background levels of $\mathrm{S}$ in lichens generally below $1000 \mu \mathrm{g} / \mathrm{g}$, with enhanced levels above this threshold. Nieboer et al. (1978) indicated values above $2,000 \mu \mathrm{g} / \mathrm{g}$ as enhanced. In Slovakia, Bačkor et al. (2003) measured S content in natural populations of lichens near a steel factory in the town of Košice by EDX microanalysis, reporting an average content of 3,900 $\mu \mathrm{g} / \mathrm{g}$ S in the crustose species Lecanora chlarotera, and 1,400 $\mu \mathrm{g} / \mathrm{g} \mathrm{S}$ in the foliose species Physcia tenella. In moss samples from Slovakia, the content of $\mathrm{S}$ is generally within the range $700-3,400 \mu \mathrm{g} / \mathrm{g}$, corresponding to an average deposition of ca. $500 \mathrm{mg} / \mathrm{m}^{2} / \mathrm{y}$ (Maňkovská and Oszlányi, 2009). As documented by instrumental monitoring, in Slovakia atmospheric $\mathrm{SO}_{2}$ production decreased from 33,400 t/y in 1990 to 9,800 t/y in 2005, and a response of sensitive lichens to this improvement was evident (Guttová et al., 2011; Lackovičová et al., 2013). However, Maňkovská and Oszlányi (2010) suspect that the main source of atmospheric $\mathrm{S}$ deposited in moss samples is the use in heavy oil combustion and the long-range transboundary pollution from Austria and the Czech Republic. Our data do not allow to infer whether the source of S is local or whether contamination originates from long range transport, since also additional measurements of $\mathrm{S}$ in a natural population of $X$. parietina from a remote site $35 \mathrm{~km} \mathrm{~W}$ of the study area were similar $(5700 \pm 211 \mu \mathrm{g} / \mathrm{g})$ to those found around the cement mill. However, in a parallel experiment, samples of the lichen Evernia prunastri taken from an unpolluted background area and exposed in the study sites progressively 
accumulated S, suggesting that this element may originate from ongoing processes (unpublished data).

Nevertheless, despite the high values of $\mathrm{S}$ in $X$. parietina samples, the low levels of other atmospheric pollutants typically associated with industrial processes ( $\mathrm{As}, \mathrm{Cd}, \mathrm{Cr}, \mathrm{Hg}, \mathrm{Pb}$ ) suggest a low contamination from combustion processes (Bargagli, 1998). Concerning Ni, the levels measured around the cement mill and the quarries $(3.2-4.1 \mu \mathrm{g} / \mathrm{g})$ indicate a moderate contamination (Bargagli and Nimis, 2002). Nickel is naturally present in fuel oils and coal (Adriano, 1986) and its concentration in lichens can be considered a good tracer of pollution from fossil fuels, power plants and metallurgical industries (Garty, 1993; Minganti et al., 2003). Cement mills are often equipped with a furnace for power generation by waste burning, therefore $\mathrm{Hg}$ can be considered an element of potential toxicological interest around this kind of source. Mercury can be released during the incineration of municipal solid waste and lichens are very efficient accumulators of $\mathrm{Hg}$ (Loppi et al., 2006; Tretiach et al., 2011). A study carried out near a cement mill in Slovenia showed a clear accumulation of this element in thalli of the lichen Pseudevernia furfuracea exposed in the surrounding environment (Ljubič Mlakar et al., 2011). In our study area, Hg contamination near the cement plant was not found in $X$. parietina. Similar indications have been reached in a parallel experiment with transplanted E. prunastri (unpublished data). The transplants of E. prunastri confirmed the results of native $X$. parietina, that the main source of contamination in the area is dust released during extraction, transportation and processing of raw materials during cement production.

Several studies deduced the occurrence of trapped particulates in lichen thalli from the similarity of Fe/Ti ratios in lichens and soil/rock material (Garty, 2001; Loppi et al., 1999). In our study, an average $\mathrm{Fe} / \mathrm{Ti}$ ratio of $12.2 \pm 0.9$ was found throughout the sampling sites. The small coefficient of variation within the whole area (7\%) witnesses the common soil/rock origin of $\mathrm{Fe}$, Ti and related elements (Al, Hg, Mn and V; Tab. 3), except for the closest urban area, where the low levels of such elements and the high Fe/Ti ratio (15.9) indicated a low rock/soil contribution to the elemental content of the lichens. However, a significant $\mathrm{Ca}$ load in native lichens showed that the closest urban area was concerned by dust depositions from the cement mill.

\section{Conclusions}

This study outlined the effects of dust contamination from a limestone quarry on the lichen diversity within a distance of $350 \mathrm{~m}$ from the source. Approaching a limestone quarry, the diffusion of basinitrophilous species, the decrease of acidophilous species and the asymmetrical distribution of the lichens on the tree boles, with a higher coverage of basiphilous species in the side facing the source were identified as the main signals of the effects induced by dust contamination. These responses, based on the functional traits of the lichen diversity, are helpful in monitoring studies around similar sources of pollution. In samples of $X$. parietina collected around the quarries and the cement mill, $\mathrm{Ca}, \mathrm{Ti}, \mathrm{Fe}, \mathrm{V}, \mathrm{Al}$ and $\mathrm{Ni}$ were significantly higher than in the surrounding environment. Accumulation of $\mathrm{Ca}$ was very useful to trace the area of high impact of the cement mill, which according to the model was within 1,700 $\mathrm{m}$ from the source. The low levels of $\mathrm{As}, \mathrm{Cd}, \mathrm{Cr}, \mathrm{Cu}, \mathrm{Hg}$, $\mathrm{Mn}, \mathrm{Pb}, \mathrm{Zn}$ suggested a reduced contamination by airborne pollutants originating from combustion processes, except for $\mathrm{S}$ and $\mathrm{Ni}$.

\section{Acknowledgements}

Research carried out in the framework of the VEGA 2/0034/13 project. We would like to thank A. Dingová and G. Kozárová for technical assistance.

\section{References}

Adams, M.D., Gottardo, C., 2012. Measuring lichen specimen characteristics to reduce relative local uncertainties for trace element biomonitoring. Atmos Pol Res 3, 325-330. Adriano, D.C., 1986. Trace elements in the terrestrial environment. Springer-Verlag. Ali, M.B., Saidur, R., Hossain, M.S., 2011. A review on emission analysis in cement industries. 
Anonymous, 2011. Správa o trvalo udržatel'nom rozvoji Holcim Slovensko 2009 - 2010. Prvé vydanie [Report on sustainable development of Holcim Slovensko 2009 - 2010. First edition; in

Asubiojo, O.I., Aina, P.O., Oluwole, A.F., Arshed, W., Akanle, O.A., Spyrou, N.M., 1991. Effects of cement production on the elemental composition of soils in the neighbourhood of two cement factories. Water Air Soil Poll 57-58, 819-828.

Bačkor, M., Loppi, S., 2009. Interactions of lichens with heavy metals. Biol Plantarum 53, 214222.

Bačkor, M., Paulíková, K., Geralská, A., Davidson, R., 2003. Monitoring of air pollution in Košice (Eastern Slovakia) using lichens. Pol J Environ Stud 12, 141-150.

Bargagli, R., 1998. Trace elements in terrestrial plants. Springer.

Bargagli, R., Nimis, P.L., 2002. Guidelines for the use of epiphytic lichens as biomonitors of atmospheric deposition of trace elements, in: Nimis, P.L., Scheidegger, C., Wolseley, P.A., (Eds.), Monitoring with Lichens - Monitoring Lichens, Kluwer Academic Publishers, Norwell, MA, pp. 295-299.

Bermudez, G.M.A., Moreno, M., Invernizzi, R., Plá, R., Pignata, M.L., 2010. Heavy metal pollution in topsoils near a cement plant: The role of organic matter and distance to the source to predict total and HCl-extracted heavy metal concentrations. Chemosphere 78, 375-381.

Bettinelli, M., Spezia, S., Bizzarri, G., 1996. Trace element determination in lichens by ICP-MS. Atom Spectros 17, 133-141.

Bluvshtein, N., Mahrer, Y., Sandler, A., Rytwo, G., 2011. Evaluating the impact of a limestone quarry on suspended and accumulated dust. Atmos Environ 45, 1732-1739.

Branquinho, C., Gaio-Oliveira, G., Augusto, S., Pinho, P., Máguas, C., Correia, O., 2008. Biomonitoring spatial and temporal impact of atmospheric dust from a cement industry. Environ Pollut 151, 292-299.

Carreras, H.A., Pignata, M.L., 2002. Biomonitoring of heavy metals and air quality in Cordoba City, Argentina, using transplanted lichens . Environ Pollut 117, 77-87.

Cembureau, 2012. Activity Report 2012. The European Cement Association, Bruxelles.

Del Guasta, M., 2000. Angular distribution of epiphytic lichens on Tilia trees as a result of car traffic. Allionia 37, 233-240.

Demiray, A.D., Yolcubal, I., Akyol, N.H., Çobanoğlu, G., 2012. Biomonitoring of airborne metals using the Lichen Xanthoria parietina in Kocaeli Province, Turkey. Ecol Indic 18, 632-643.

Farmer, A.M., 1993 The effects of dust on vegetation - A review. Environ Pollut 79, 63-75.

Farmer, A.M., Bates, J.W., Bell, J.B.N., 1990. A comparison of methods for the measurement of bark pH. Lichenologist 22, 191-194.

Ferry, B.W., Baddeley, M.S., Hawksworth, D.L., (Eds.) 1973. Lichens and Air Pollution. University of Toronto Press, Toronto.

Garty, J., 1993. Lichens as biomonitors for heavy metal pollution, in: Markert, B., (Ed.), Plants as biomonitors. Indicators for heavy metals in the terrestrial environment. VCH, Weinheim, pp. 193-263.

Garty, J., Garty-Spitz, R.L., 2011. Neutralization and neoformation: analogous processes in the atmosphere and in lichen thalli - A review. Environ Exp Bot 70, 67-79.

Garty, J., 2001. Biomonitoring atmospheric heavy metals with lichens: theory and application. Crit Rev Plant Sci 20, 309-371.

Gilbert, O.L., 1976. An alkaline dust effect on epiphytic lichens. Lichenologist 8, 173-178.

Guttová, A., Lackovičová, A., Pišút, I., Pišút, P., 2011. Decrease in air pollution load in urban environment of Bratislava (Slovakia) inferred from accumulation of metal elements in lichens. Environ Monit Assess 182, 361-373.

Guttová, A., Lackovičová, A., Pišút, I., 2013. Revised and updated checklist of lichens of Slovakia (May 2013). Biologia 68, 845-850.

\section{Härte1, O., Grill, D., 1972. Die Leitfähigkeit von Fichtenborken-Extrakten als empfindlicher}


Holobradý, K., Tóth, J., 1967. Vplyv tuhých aerosólovích častíc z cementární na pol’nohospodárskeplodiny a pôdu, in: Hauskrecht, J., Zeleňáková, E., (Eds.), Problémy znečist'ovania ovzdušia. Zborník materiálov z II. Sympózia o problematike exhalátov na Slovensku. Smolenice 1415.10.1967, SAV, Bratislava.

Jalkanen, L., Mäkinen, A., Häsänen, E., Juhanoja, J. 2000. The effect of large anthropogenic particulate emissions on atmospheric aereosol, deposition and bioindicators in the eastern Gulf of Finland region. Sci Total Environ 30, 123-136.

Jürging, P., 1975. Epiphytische Fletchen als Bioindikatoren der Luftverunreinigung: Dargestellt an Untersuchungen Und Beobachtungen in Bayern. Bibl Lichenol 4, 1-164.

Lackovičová, A., 1982. Epifytické lišajníky a čistota ovzdušia v južnej časti Malých Karpát. Autoreferát dizertácie [Epiphytic lichens and air quality in the southern part of the Malé Karpaty Mts. Summary of the dissertation thesis. In Slovak]. ÚEBE SAV, Bratislava.

Lackovičová, A., Guttová, A., Bačkor, M., Pišút, P., Pišút, I., 2011. Response of Evernia prunastri to urban environmental conditions in Central Europe after the decrease of air pollution. Lichenologist 45, 89-100.

Lapin, M., Faško, P., Melo, M., Št’astný, P., Tomlain, J. 2002. Klimatické oblasti. Mapa 1 : 1000000. In: Atlas krajiny Slovenskej republiky. Ministerstvo životného prostredia Bratislava, Agentúra životného prostredia Banská Bystriea.

Lisická, E., 1976. Poznámky k vplyuu niektorých typov exhalaěných splodín na epifytieké lišajníky. Acta Faeultatis Rerum Naturalium Universitatis Comeniana Formatio Et Protectio Naturae 1, $83-87$.

Loppi, S., 1996. Effects of road dust contamination on epiphytic lichen communities (central Italy). Micologia \& Vegetazione Mediterranea 11, 155-160.

Loppi, S., De Dominicis, V., 1996. Effects of agriculture on epiphytic lichen vegetation in central Italy. Israel J Plant Sci 44, 297-307.

Loppi, S., Cenni, E., Bussotti, F., Ferretti, M., 1998. Biomonitoring of geothermal air pollution by epiphytic lichens and forest trees. Chemosphere 36, 1079-1082.

Loppi, S., Paoli, L., Gaggi, C., 2006. Diversity of epiphytic lichens and Hg of Xanthoria parietina thalli as monitors of geothermal air pollution in the Mt. Amiata (Central Italy). J Atmos Chem 53, 93-105.

Loppi S., Pirintsos S.A., 2000. Effect of dust on epiphytic lichen vegetation in the Mediterranean area (Italy and Greece). Israel J Plant Sci 48, 91-95.

Loppi, S., Pirintsos, S.A., De Dominicis, V., 1999. Soil contribution to the elemental composition of epiphytic lichens (Tuscany, central Italy). Environ Monit Assess 58, 121-131.

Ljubič Mlakar, T., Kotnik, J., Jeran, Z., Vuk, T., Mrak, T., Fajon, V., 2011. Biomonitoring with epiphytic lichens as a complementary method for the study of mercury contamination near a cement plant. Environ Monit Assess 181, 225-241.

Maňkovská, B., Oszlányi, J., 2009. Temporal trends (1990-2005) in heavy metal accumulation in mosses in Slovakia. Ann Forest Res 52, 55-62.

Maňkovská, B., Oszlányi, J., 2010. Long term air pollution studies (1990-2005) in báb research sites using the moss biomonitoring technique. Ekologia (Bratislava) 29, 40-46.

Marmor, L., Tõrra, T., Randlane, T., 2010. The vertical gradient of bark pH and epiphytic macrolichen biota in relation to alkaline air pollution. Ecol Indic 10, 1137-1143.

Minganti, V., Capelli, R., Drava, G., De Pellegrini, R., Brunialti, G., Giordani, P., Modenesi, P., 2003. Biomonitoring of trace metals by different species of lichens (Parmelia) in North-West Italy. J Atmos Chem 45, 219-229.

Mitášová, H., Mitáš, L., 1993. Interpolation by regularized spline with tension: I. Theory and implementation. Mat Geol 25/6, 641-655.

Nieboer, E., Richardson, D.H.S., Tomassini, F.D., 1978. Mineral uptake and release by lichens: an overview. Bryologist 81, 226-246.

Nimis, P.L., Martellos, S., 2008. ITALIC-The information system on Italian Lichens. Version 4.0. 
University of Trieste, Dept. of Biology, IN4.0/1 (http://dbiodbs.univ.trieste.it/) .

Nimis, P.L., Scheidegger, C., Wolseley, P.A., 2002. Monitoring with lichens-monitoring lichens. NATO Science Series. Kluwer Academic Publishers, Norwell, MA.

Paoli, L., Guttová, A., Loppi, S., 2006. Assessment of environmental quality by the diversity of epiphytic lichens in a semi-arid mediterranean area (Val Basento, South Italy). Biologia 61, 353359.

Paoli, L., Munzi, S., Fiorini, E., Gaggi, C., Loppi, S., 2013. Influence of angular exposure and proximity to vehicular traffic on the diversity of epiphytic lichens and the bioaccumulation of traffic-related elements. Environ Sci Pollut R 20, 250-259.

Pignata, M.L., Plá, R.R., Jasan, R.C., Martinez, M.S., Rodriguez, J.H., Wannaz, E.D., Gudino, G.L., Carreras, H.A., González, C.M., 2007. Distribution of atmospheric trace elements and assessment of air quality in Argentina employing the lichen Ramalina celastri, as a passive biomonitor: detection of air pollution sources. Int J Environ Heal 1, 29-46.

Pišút, I., Lisická-Jelínková, E., 1974. Epiphytische Fletchen in der Umgebung einer Aluminiumhütte in der Mittelslowakei. Biologia 29, 29-38.

Pišút, I., Pišút, P., 2006. Changes of epiphytic lichens in the surroundings of magnesite factories near Jelšava (SE Slovakia) in the period 1973-2004. Ekológia (Bratislava) 25, 176-187.

Recchia F., Pacioni G., Fucetola F., 1991. L'inquinamento da polveri di cementificio valutato con licheni come bioindicatori. Micologia \& Vegetazione Mediterranea 6, 165-172.

Recchia F., Polidoro F., 1988. Osservazioni sui licheni nelle vicinanze di un cementificio. Archivio Botanico \& Biogeografico Italiano 64, 8-18.

Richardson, D.H.S., 1981. Pollution monitoring with lichens (Naturalists' Handbooks 19). The Richmond Publishing Co. Ltd., Slough, England.

Schuhmacher, M., Domingo, J.L., Garreta, J., 2004. Pollutants emitted by a cement plant: health risks for the population living in the neighborhood. Environ Res 95, 198-206.

ter Braak, C.J.F., Šmilauer, P., 2002. CANOCO reference manual and CanoDraw for Windows user 's guide. Software for canonical community ordination (version 4.5). Biometrics, Wageningen \& České Budějovice.

Tretiach, M., Candotto Carniel, F., Loppi, S., Carniel, A., Bortolussi, A., Mazzilis, D., Del Bianco, C., 2011. Lichen transplants as a suitable tool to identify mercury pollution from waste incinerators: a case study from NE Italy. Environ Monit Assess 175, 589-600.

Zaharopoulou, A., Lanaras, T., Arianoutsou, M., 1993. Influence of dust from a limestone quarry on chlorophyll degradation of the lichen Physcia adscendens (Fr.) Oliv. B Environ Contam Tox 50, $852-855$. 
573 Figure 1. Study area with formal localization of the sampling sites: 1) cement mill (48 $27^{\prime} 23^{\prime \prime} \mathrm{N}$, $\left.57417^{\circ} 11^{\prime} 43^{\prime \prime} \mathrm{E}\right)$; 2) limestone quarry $\left(48^{\circ} 26^{\prime} 46^{\prime \prime} \mathrm{N}, 1^{\circ} 12^{\prime} 41^{\prime \prime} \mathrm{E}\right)$; 3$)$ paleobasalt quarry $\left(48^{\circ} 26^{\prime} 39^{\prime} \mathrm{N}\right.$, $\left.57517^{\circ} 13^{\prime} 51^{\prime \prime} \mathrm{E}\right)$; 4) urban area $\left.\left(48^{\circ} 27^{\prime} 51^{\prime \prime} \mathrm{N}, 1^{\circ} 09^{\prime} 58^{\prime \prime} \mathrm{E}\right) ; 5\right)$ agricultural area (sampling points from $5763\left(48^{\circ} 28^{\prime} 09^{\prime \prime} \mathrm{N}, 17^{\circ} 13^{\prime} 13^{\prime \prime} \mathrm{E}\right)$ to $5 \mathrm{~km}\left(48^{\circ} 28^{\prime} 46^{\prime \prime} \mathrm{N}, 17^{\circ} 15^{\prime} 04^{\prime \prime} \mathrm{E}\right)$ from the cement mill); 6) 577 agricultural area $\left(48^{\circ} 30^{\prime} 12^{\prime \prime} \mathrm{N}, 17^{\circ} 17^{\prime} 42^{\prime \prime} \mathrm{E}\right.$; $10 \mathrm{~km}$ from the cement mill).

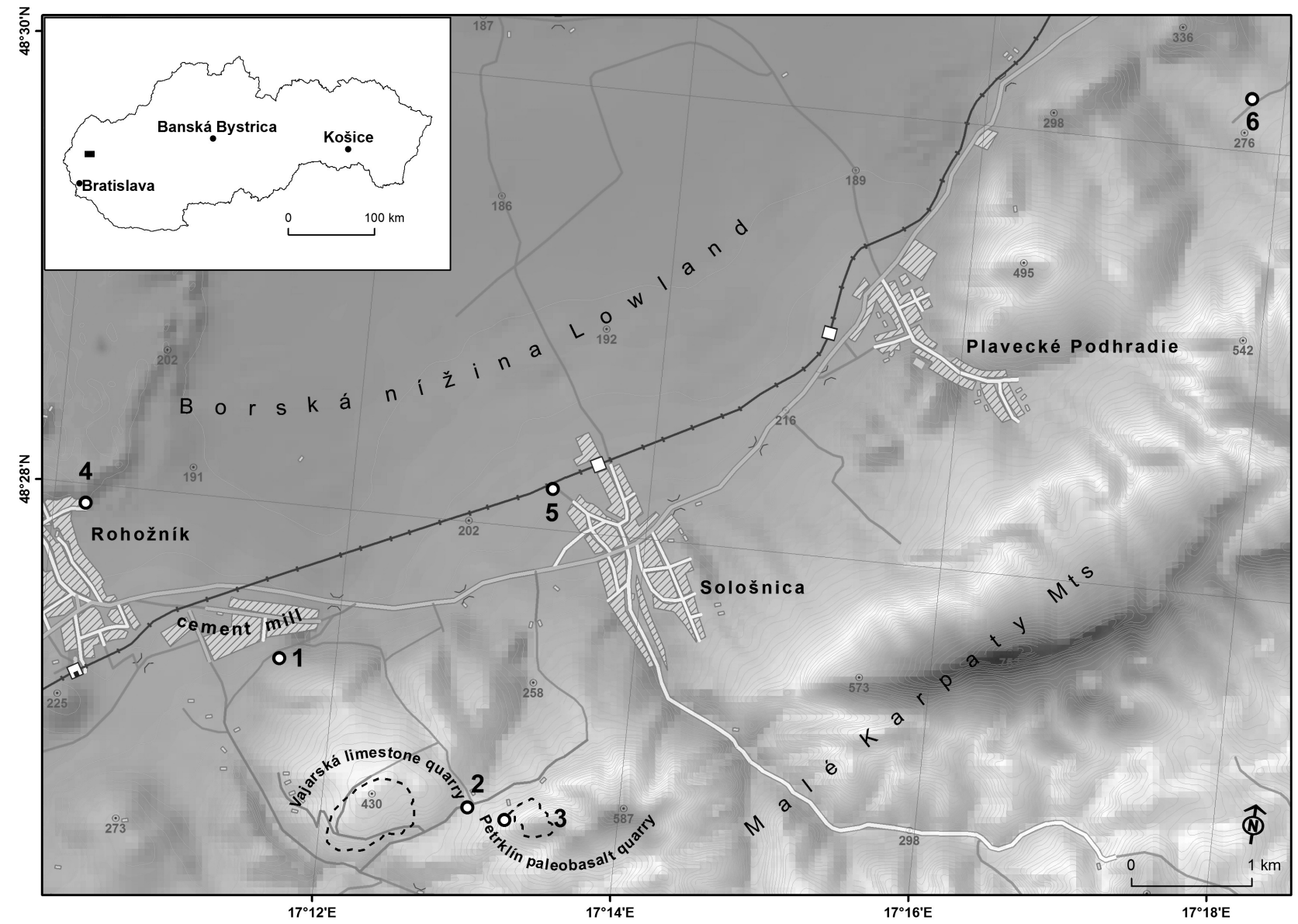


601 Table 1. Index of lichen diversity (ILD) combining vitality-abundance of the lichens on the border 602 of the limestone quarry and at a distance of $350 \mathrm{~m}$, on the exposed and sheltered side of the boles. 603 Acidophilous $\left({ }^{a}\right)$, basiphilous $\left({ }^{b}\right)$ and nitrophilous $\left({ }^{\mathrm{n}}\right)$ species; percentage of relevés where the 604 species was present over total relevés (P\%). In brackets abbreviations used in detrended 605 correspondence analysis. * Significant difference (Kolmogorov-Smirnov test, $p<0.05$ ).

606

\begin{tabular}{|c|c|c|c|c|c|}
\hline \multirow[t]{2}{*}{ Species } & \multirow[t]{2}{*}{$\mathbf{P \%}$} & \multicolumn{2}{|c|}{$\begin{array}{l}\text { ILD at the limestone } \\
\text { quarry }\end{array}$} & \multicolumn{2}{|c|}{$\begin{array}{l}\text { ILD at } 350 \mathrm{~m} \text { from the } \\
\text { quarry }\end{array}$} \\
\hline & & $\begin{array}{l}\text { Exposed } \\
\text { side }\end{array}$ & $\begin{array}{c}\text { Sheltered } \\
\text { side }\end{array}$ & $\begin{array}{c}\text { Exposed } \\
\text { side }\end{array}$ & $\begin{array}{c}\text { Sheltered } \\
\text { side }\end{array}$ \\
\hline $\begin{array}{l}\text { Phaeophyscia orbicularis (Neck.) Moberg } \\
\text { (po) }{ }^{\mathrm{b}, \mathrm{n}}\end{array}$ & 45 & 5 & 3 & & \\
\hline Xanthoria parietina (L.) Th.Fr. (xp) ${ }^{\mathrm{b}, \mathrm{n}}$ & 48 & 3 & 3 & & \\
\hline $\begin{array}{l}\text { Phaeophyscia nigricans (Flörke) Moberg } \\
\text { (pn) }{ }^{\mathrm{b}, \mathrm{n}}\end{array}$ & 42 & 3 & 1 & & \\
\hline Caloplaca pyracea (Ach.) Th.Fr. (ch) ${ }^{\mathrm{b}, \mathrm{n}}$ & 29 & 3 & 1 & & \\
\hline Physcia adscendens (Fr.) H.Olivier (py) ${ }^{\mathrm{b}}$ & 52 & 3 & 5 & 1 & \\
\hline Lecanora chlarotera $\mathrm{Nyl} .(\mathrm{lt})^{\mathrm{a}, \mathrm{n}}$ & 26 & 3 & 3 & & \\
\hline $\begin{array}{l}\text { Amandinea punctata (Hoffm.) Coppins \& } \\
\text { Scheid. (ap) }\end{array}$ & 26 & 3 & & & \\
\hline Lecania cyrtella (Ach.) Th.Fr. (lc) a & 29 & 3 & 1 & 1 & \\
\hline $\begin{array}{l}\text { Caloplaca cerinelloides (Erichsen) Poelt } \\
(\mathrm{cc})^{\mathrm{b}, \mathrm{n}}\end{array}$ & 19 & 1 & 1 & & \\
\hline $\begin{array}{l}\text { Scoliciosporum umbrinum (Ach.) Arnold } \\
(\mathrm{su})^{\mathrm{a}}\end{array}$ & 10 & 1 & 1 & 1 & \\
\hline $\begin{array}{l}\text { Candelariella xanthostigma (Ach.) Lettau } \\
(\mathrm{cx})^{\mathrm{a}}\end{array}$ & 52 & 3 & 1 & 1 & 1 \\
\hline Phlyctis argena (Spreng.) Flot. (pg) ${ }^{\mathrm{a}}$ & 10 & 3 & 1 & 1 & 1 \\
\hline $\begin{array}{l}\text { Lecidella elaeochroma (Ach.) M.Choisy } \\
\text { (le) })^{a, b, n}\end{array}$ & 16 & 1 & & 1 & 1 \\
\hline Lepraria $\mathrm{sp} .(\mathrm{ls})^{\mathrm{a}}$ & 10 & & 1 & & 1 \\
\hline $\begin{array}{l}\text { Scoliciosporum chlorococcum (Stenh.) } \\
\text { Vězda (sc) }{ }^{\text {a }}\end{array}$ & 6 & & & 3 & 1 \\
\hline Graphis scripta (L.) Ach. (gs) ${ }^{\text {a }}$ & 3 & & & & 1 \\
\hline Physcia sp. juv. & 3 & & & & 1 \\
\hline Lecanora carpinea $(\mathrm{L}$.$) Vain. (lp) { }^{\mathrm{a}, \mathrm{b}}$ & 19 & 3 & 1 & 1 & 3 \\
\hline Porina aenea (Wallr.) Zahlbr. (pe) ${ }^{\text {a }}$ & 39 & 1 & 3 & 3 & 3 \\
\hline Lecanora subcarpinea Szatala (la) a & 32 & 1 & 3 & 3 & 3 \\
\hline Pyrenula nitida (Weigel) Ach. (pi) ${ }^{\text {a }}$ & 26 & & & 1 & 3 \\
\hline Arthonia radiata (Pers.) Ach. (ar) ${ }^{a}$ & 23 & & & 1 & 3 \\
\hline Lecanora sp. (1) & 16 & 1 & 1 & 1 & 5 \\
\hline ILD per side of the bole & & $20 \pm 6 *$ & $10 \pm 6 *$ & $7 \pm 3$ & $10 \pm 4$ \\
\hline pH of the bark per side of the bole & & $6.1 \pm 0.2 *$ & $5.7 \pm 0.1 *$ & $5.3 \pm 0.3$ & $5.3 \pm 0.3$ \\
\hline Total ILD per site & & $30 \pm$ & $10 *$ & & $5 *$ \\
\hline pH of the bark per site & & $5.9 \pm$ & $0.3 *$ & 5.3 & $.3 *$ \\
\hline
\end{tabular}


611 Figure 2. Detrended correspondence analysis (DCA): ordination diagram of the relevés. Black 612 diamonds - relevés scored along the limestone quarry and grey circles - relevés at a distance of 350 $613 \mathrm{~m}$ (present study); grey squares - relevés in natural Fagus sylvatica stands in 1970s. White triangles 614 - lichen species.

615

616

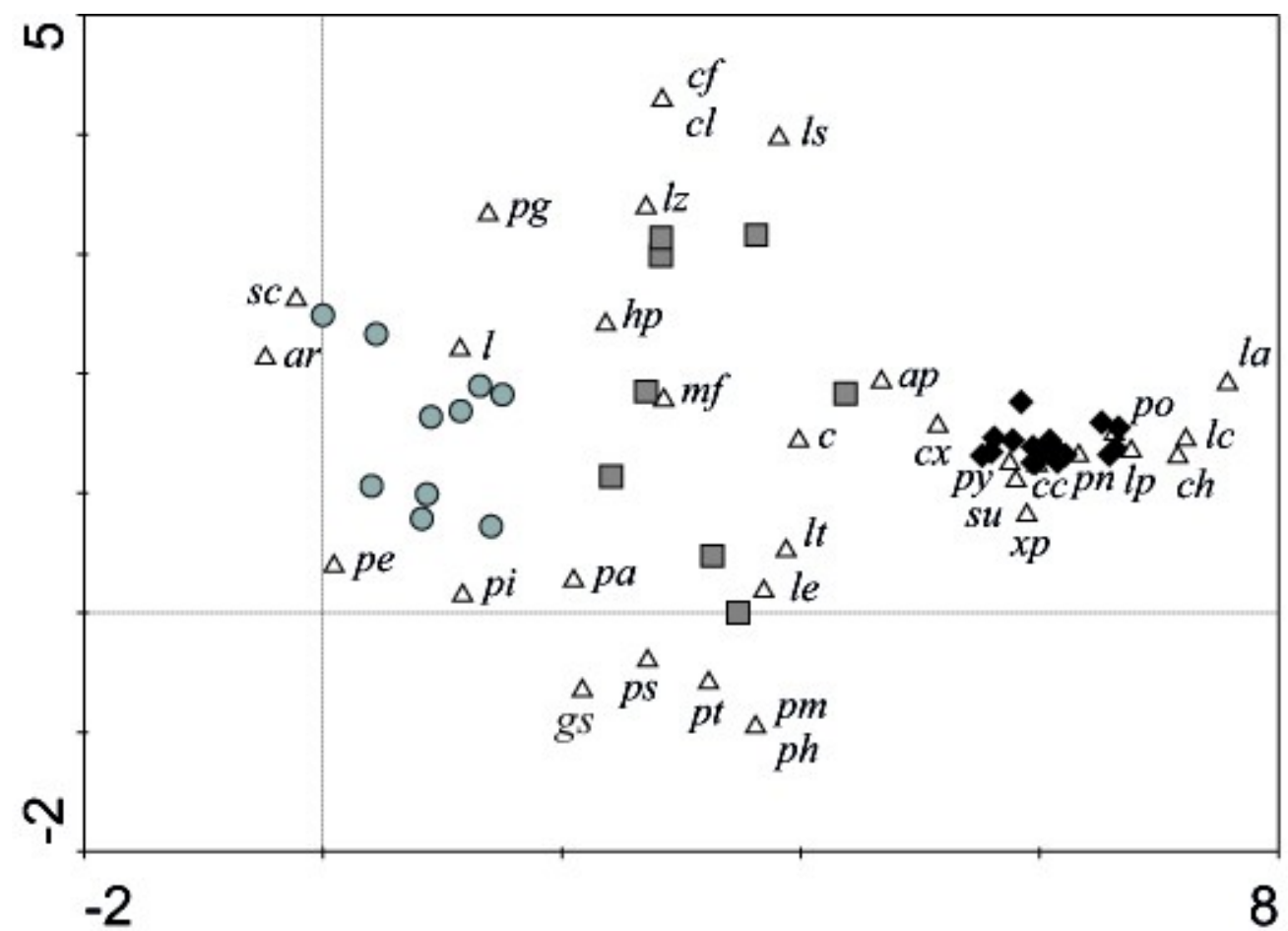

617
For abbreviations of species scored in this study and in 1970s see Tab. 1; species recorded only in 1970s: Cladonia coniocraea (cl), C. fimbriata (cf), Cladonia sp. (c), Hypogymnia physodes (hp), Lecanora conizaeoides (lz), Melanelixia fuliginosa (mf), Parmelia sulcata (ps), Parmelina tiliacea (pt), Pertusaria amara (pm), Physconia grisea (ph). Cumulative percentage variance of species data on first two axes $23.2 \%$; eigenvalues for first two axes 0.900 and 0.335 respectively; lengths of gradients for first two axes 6.663 and 3.160 respectively. 
643

644 Figure 3. Functional traits of lichen diversity expressed as Index of Lichen Diversity (ILD, 645 acidophilous vs basiphilous species) on the boles of Fagus sylvatica at the limestone quarry and $646350 \mathrm{~m}$ from the border of the quarry.

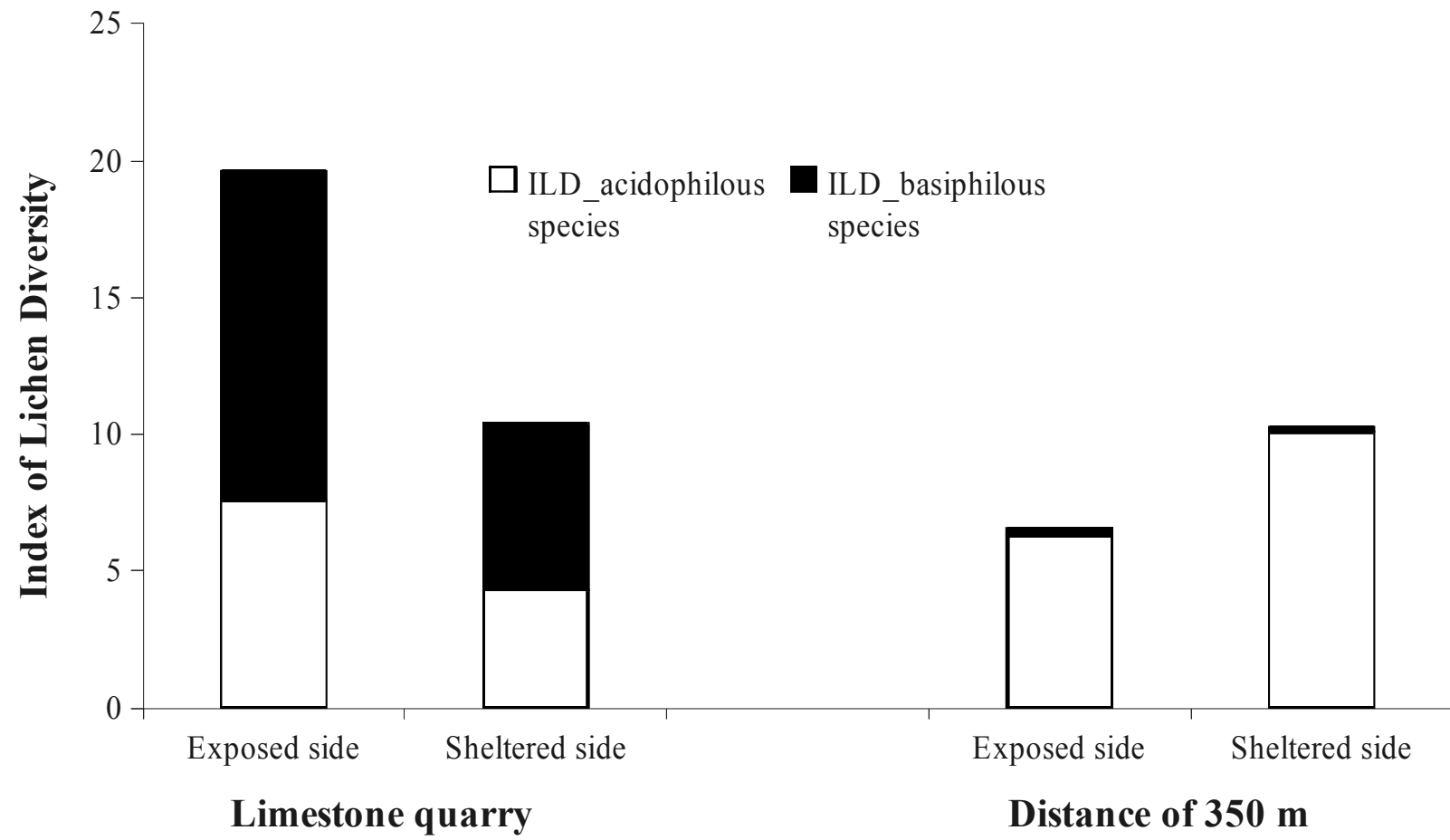


676 Table 2. Average of element concentrations $\pm \mathrm{SD}(\mu \mathrm{g} / \mathrm{g})$ measured in native Xanthoria parietina.

677 Distances refer to the cement mill. Values in bold are significantly higher respect to the agricultural 678 sites $(3-10 \mathrm{~km}$ of distance) (Kolmogorov-Smirnov test, $p<0.05)$.

679

\begin{tabular}{lccccc}
\hline \multirow{2}{*}{ Sampling sites } & \multicolumn{5}{c}{ Element concentrations } \\
\cline { 2 - 6 } Cement mill & $\mathbf{C a}$ & $\mathbf{T i}$ & $\mathbf{F e}$ & $\mathbf{V}$ & $\mathbf{A l}$ \\
\cline { 2 - 6 } Limestone quarry & $\mathbf{2 , 4 6 0} \pm \mathbf{1 2 3}$ & $\mathbf{4 8} \pm \mathbf{5}$ & $\mathbf{6 0 4} \pm \mathbf{1 0 9}$ & $\mathbf{1 . 9} \pm \mathbf{0 . 1}$ & $\mathbf{2 9 5} \pm \mathbf{5 3}$ \\
Paleobasalt quarry & $\mathbf{1 , 6 3 0} \pm \mathbf{8 2}$ & $\mathbf{4 8} \pm \mathbf{5}$ & $\mathbf{5 5 5} \pm \mathbf{1 0 0}$ & $\mathbf{1 . 5} \pm \mathbf{0 . 1}$ & $\mathbf{3 0 0} \pm \mathbf{5 4}$ \\
Urban $(1.5 \mathrm{~km})$ & $\mathbf{2 , 0 2 0} \pm \mathbf{1 0 1}$ & $\mathbf{2 9 6} \pm \mathbf{3 0}$ & $\mathbf{3 , 4 6 0} \pm \mathbf{6 2 3}$ & $\mathbf{6 . 4} \pm \mathbf{0 . 4}$ & $\mathbf{8 2 9} \pm \mathbf{1 4 9}$ \\
Agricultural $(3 \mathrm{~km})$ & $\mathbf{1 , 4 5 0} \pm \mathbf{7 3}$ & $18 \pm 2$ & $287 \pm 52$ & $0.7 \pm 0.1$ & $131 \pm 24$ \\
Agricultural (10 km) & $1,097 \pm 25$ & $29 \pm 13$ & $349 \pm 145$ & $1 \pm 0.4$ & $182 \pm 75$ \\
& $1,110 \pm 56$ & $24 \pm 3$ & $329 \pm 59$ & $1 \pm 0.1$ & $202 \pm 36$ \\
& & & & & \\
Cement mill & $\mathbf{N i}$ & $\mathbf{M n}$ & $\mathbf{H g}$ & $\mathbf{S}$ & $\mathbf{C u}$ \\
Limestone quarry & $\mathbf{4 . 1} \pm \mathbf{0 . 4}$ & $\mathbf{2 7} \pm \mathbf{1}$ & $0.02 \pm 0.01$ & $5,110 \pm 256$ & $4.6 \pm 0.9$ \\
Paleobasalt quarry & $\mathbf{3 . 2} \pm \mathbf{0 . 3}$ & $23 \pm 1$ & $0.02 \pm 0.01$ & $2,940 \pm 147$ & $3.0 \pm 0.6$ \\
Urban (1.5 km) & $\mathbf{3 . 3} \pm \mathbf{0 . 3}$ & $\mathbf{8 9} \pm \mathbf{4}$ & $\mathbf{0 . 0 7} \pm \mathbf{0 . 0 1}$ & $4,220 \pm 211$ & $4.0 \pm 0.8$ \\
Agricultural (3 km) & $1.9 \pm 0.2$ & $17 \pm 1$ & $\mathbf{0 . 0 5} \pm \mathbf{0 . 0 1}$ & $4,310 \pm 216$ & $3.3 \pm 0.7$ \\
Agricultural (10 km) & $2.1 \pm 0.7$ & $20 \pm 2$ & $0.02 \pm 0.01$ & $5,207 \pm 878$ & $4.5 \pm 1.1$ \\
& $2.1 \pm 0.4$ & $23 \pm 1$ & $0.02 \pm 0.01$ & $5,720 \pm 286$ & $4.6 \pm 0.9$ \\
& & & & & \\
Cement mill & $\mathbf{A s}$ & $\mathbf{C d}$ & $\mathbf{P b}$ & $\mathbf{C r}$ & $\mathbf{Z n}$ \\
Limestone quarry & $0.50 \pm 0.03$ & $\mathbf{0 . 2 8} \pm \mathbf{0 . 0 3}$ & $\mathbf{3 . 4} \pm \mathbf{0 . 1}$ & $2.0 \pm 0.1$ & $34 \pm 2$ \\
Paleobasalt quarry & $\mathbf{0 . 8 0} \pm \mathbf{0 . 0 4}$ & $\mathbf{0 . 3 0} \pm \mathbf{0 . 0 3}$ & $\mathbf{2 . 4} \pm \mathbf{0 . 1}$ & $1.6 \pm 0.1$ & $43 \pm 3$ \\
Urban (1.5 km) & $0.37 \pm 0.02$ & $0.24 \pm 0.02$ & $2.0 \pm 0.1$ & $2.1 \pm 0.1$ & $30 \pm 2$ \\
Agricultural (3 km) & $0.56 \pm 0.19$ & $0.21 \pm 0.04$ & $1.8 \pm 0.3$ & $1.7 \pm 0.4$ & $33 \pm 8$ \\
Agricultural (10 km) & $0.47 \pm 0.02$ & $0.20 \pm 0.02$ & $1.6 \pm 0.1$ & $1.6 \pm 0.1$ & $39 \pm 3$ \\
\hline & & & & & \\
\hline
\end{tabular}

680

681

682

683

684

685

686

687

688

689

690

691

692

693

694

695

696

697

698

699 
704 Table 3. Pearson correlation coefficients between pairs of elements in native Xanthoria parietina.

705 Only significant values are given $(* p<0.05 ; * *<<0.01 ; * * *<<0.001)$.

706

\begin{tabular}{|c|c|c|c|c|c|c|c|c|c|c|c|c|c|c|c|}
\hline & $\overline{\mathrm{Al}}$ & $S$ & $\mathrm{Ca}$ & $\mathrm{Ti}$ & $\mathrm{V}$ & $\mathrm{Cr}$ & $\mathrm{Mn}$ & $\mathrm{Fe}$ & $\mathrm{Ni}$ & $\overline{\mathrm{Cu}}$ & $\mathrm{Zn}$ & As & $\overline{\mathrm{Cd}}$ & $\mathrm{Hg}$ & $\overline{\mathrm{Pb}}$ \\
\hline $\mathrm{Al}$ & - & & & & & & & & & & & & & & \\
\hline $\mathrm{S}$ & - & - & & & & & & & & & & & & & \\
\hline $\mathrm{Ca}$ & - & - & - & & & & & & & & & & & & \\
\hline $\mathrm{Ti}$ & $0.98^{* * *}$ & - & - & - & & & & & & & & & & & \\
\hline V & $0.99 * * *$ & - & - & $0.99 * * *$ & - & & & & & & & & & & \\
\hline $\mathrm{Cr}$ & - & - & - & - & - & - & & & & & & & & & \\
\hline $\mathrm{Mn}$ & $0.98^{* * *}$ & - & - & $1.00^{* * *}$ & $0.99 * * *$ & - & - & & & & & & & & \\
\hline $\mathrm{Fe}$ & $0.98^{* * *}$ & - & - & $1.00^{* * *}$ & $0.99^{* * *}$ & - & $1.00^{* * *}$ & - & & & & & & & \\
\hline $\mathrm{Ni}$ & - & - & - & - & - & - & - & - & - & & & & & & \\
\hline $\mathrm{Cu}$ & - & $0.91 * *$ & - & - & - & - & - & - & - & - & & & & & \\
\hline $\mathrm{Zn}$ & - & - & - & - & - & - & - & - & - & - & - & & & & \\
\hline As & - & - & - & - & - & - & - & - & - & - & - & - & & & \\
\hline $\mathrm{Cd}$ & $0.72 *$ & - & - & - & - & - & - & - & - & - & - & - & - & & \\
\hline $\mathrm{Hg}$ & - & - & - & $0.76^{*}$ & $0.71^{*}$ & - & $0.76^{*}$ & $0.76^{*}$ & - & - & - & - & - & - & \\
\hline $\mathrm{Pb}$ & - & - & $0.73^{*}$ & - & - & - & - & - & - & - & - & - & - & - & - \\
\hline
\end{tabular}

709 Figure 4. GIS model of Ca depositions in native thalli of the lichen Xanthoria parietina.

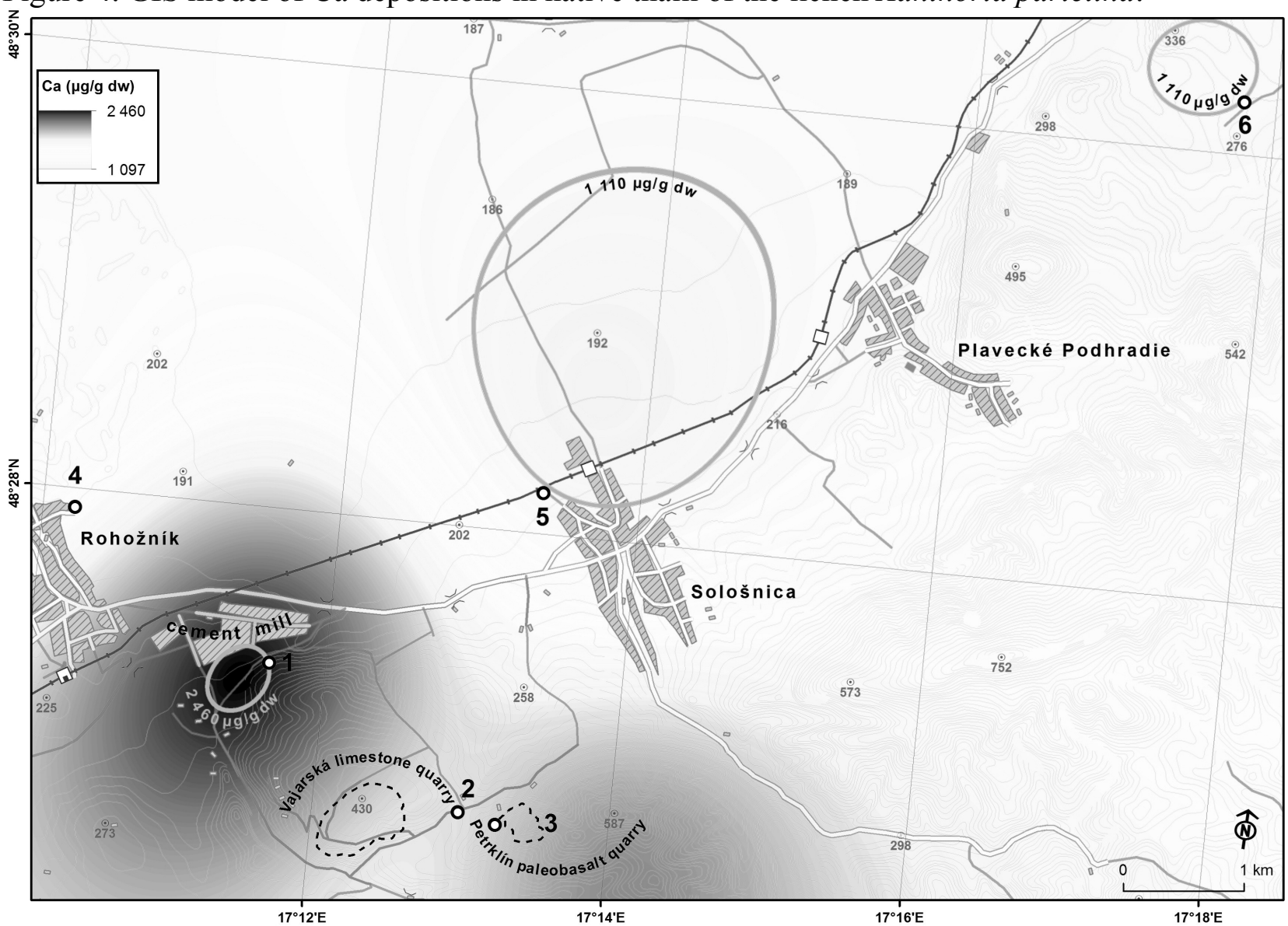

